\title{
Antagonistic proliferative activities of adiponectin and leptin in breast cancer: study on MCF7 cells
}

\author{
T. Jardé ${ }^{1}$, F. Caldefie-Chézet ${ }^{1}$, M. Damez ${ }^{1}$, F. Mishellany ${ }^{2}$, C. Buechler ${ }^{3}$, D. Bernard-Gallon ${ }^{4}$, \\ F. Penault-Llorca ${ }^{2}$, J. Guillot ${ }^{1}$ and M. P. Vasson ${ }^{5}$ \\ ${ }^{1}$ Univ Clermont 1, UFR Pharmacie, EA2416, Clermont-Ferrand, France, ${ }^{2}$ Centre Jean-Perrin, Laboratoire \\ d'Anatomopathologie, Clermont-Ferrand, France, ${ }^{3}$ Département de Médecine Interne I, Université de Regensburg, \\ Regensburg, France, ${ }^{4}$ Centre Jean-Perrin, Département d'Oncogénétique, Clermont-Ferrand, France and \\ ${ }^{5}$ Univ Clermont 1, UFR Pharmacie, EA2416, Centre Jean-Perrin, Unité de Nutrition, Clermont-Ferrand, France
}

\begin{abstract}
Adiponectin and leptin are two adipokines essentially synthesized by adipose tissue. Obesity, which is a risk factor for breast cancer in menopausal women, is characterized by low serum adiponectin levels and high serum leptin levels. Thus, the aim of the present study was to determine the involvement of adiponectin and leptin in breast cancer development. The expression of adiponectin, leptin and their receptors (AdipoR1, AdipoR2 and Ob-R respectively) was investigated in MC7 breast cancer cells as well as the influence of these adipokines on the proliferation of MCF7 cancer cells.

The expression of adiponectin, leptin and their corresponding receptors was analysed by immunohistochemistry in MCF7 cells ( $n$ 3). The cellular proliferation was measured by using a fluorescent method (resazurin). Briefly, MCF7 cells were exposed to adiponectin (1 or $10 \mu \mathrm{g} / \mathrm{ml})$, leptin $(0.1$ and $1 \mu \mathrm{g} / \mathrm{ml})$ or both adiponectin and leptin (each at $1 \mu \mathrm{g} / \mathrm{ml})$ for $24,48,72$ and $96 \mathrm{~h}$. The cells were then incubated with the resazurin solution $(25 \mu \mathrm{g} / \mathrm{ml})$, in which the fluorescent intensity was proportional to the number of living cells. The statistical analysis was performed using a paired Student's $t$ test $(P<0.05)$.

Adiponectin, leptin and their corresponding receptors were detected in MCF7 cells. Adiponectin $(10 \mu \mathrm{g} / \mathrm{ml})$ significantly decreased the proliferation of breast cancer cells to $10,13,18$ and $20 \%$ at $24,48,72$ and $96 \mathrm{~h}$ respectively. At $1 \mu \mathrm{g} / \mathrm{ml}$, adiponectin significantly inhibited the proliferation to $7 \%$ at $72 \mathrm{~h}$. In contrast, leptin $(1 \mu \mathrm{g} / \mathrm{ml})$ significantly enhanced the proliferation of MCF7 cells by 8,13 and $20 \%$ at 48,72 and $96 \mathrm{~h}$ respectively, but was ineffective at $0.1 \mu \mathrm{g} / \mathrm{ml}$. Proliferation was not affected in MCF7 cells co-incubated with adiponectin $(1 \mu \mathrm{g} / \mathrm{ml})$ and leptin $(1 \mu \mathrm{g} / \mathrm{ml})$ simultaneously for $24,48,72$ or $96 \mathrm{~h}$.

AdipoR1, AdipoR2 and Ob-R protein were detected in MCF7 cells. Adiponectin mediates an antiproliferative response in breast cancer cells whereas leptin stimulates the growth of MCF7 cells, indicating that these adipokines exert antagonistic activities on breast cancer cell proliferation. In addition, adiponectin and leptin, detected in MCF7 cells, may act on cancer cells via an autocrine and/or paracrine pathway. The strong relationship between adipokines and breast carcinogenesis opens new perspectives for investigations and therapeutic options, particularly for obese women.
\end{abstract}

